\title{
Peran Ilmu Politik Dalam Mendukung Hak Asasi Manusia di Indonesia
}

\author{
Vita Justisia \\ Fakultas Ilmu Sosial dan Ilmu Politik Universitas Islam Negeri Raden Fatah \\ Email: vjjustsvita@gmail.com
}

\begin{abstract}
Human rights is an idea that have a long process in the history of human civilization. Human rights always have a correlative relationship with human duty because of the nature of human nature as individuals and social beings. Human Rights has incuded in the Constitution of the Republic Indonesia UUD-RI 1945. The history of the Indonesian nation records the occurrence of various gross human rights violations such as crimes against humanity that occurred in East Timor, Aceh, Jakarta and in some other areas that have not completed the handling, whereas in the field of legislation of the Government of Indonesia has made various efforts to make laws and ratify them from various international instruments on human rights. This is due to the unrelated legislation existing with the political will of the government. Political science is concerned with the state's governance, State's governance deals with key officials setting policy directions including human rights policies. For the public it is important to study political science so that the public can contribute to the political will of the government in the field of law enforcement of human rights in Indonesia.
\end{abstract}

Keywords: role, political science, human rights

\begin{abstract}
Abstrak
Hak-hak Asasi Manusia adalah gagasan yang telah melewati proses yang cukup panjang dalam peradaban sejarah manusia. Hak-hak asasi manusia senantiasa memiliki hubungan yang korelatif dengan wajib asasi manusia karena sifat kodrat manusia sebagai individu dan makhluk sosial. UUD-RI 1945 sebagai konsitusi tertulis bangsa Indonesia mencantumkan Hak Asasi Manusia ini baik dalam pembukaan maupun dalam batang tubuh nya serta penjelasan UUD-RI 1945. Sejarah bangsa Indonesia mencatat terjadinya berbagai pelanggaran HAM yang berat seperti kejahatan kemanusiaan yang terjadi di Timor Timur, Aceh, Jakarta dan di beberapa daerah lainnya yang belum tuntas penanganannya, padahal dibidang perundang-undangan Pemerintah Indonesia telah melakukan berbagai upaya untuk membuat undang undang maupun meratifikasinya dari berbagai instrumen internasional tentang HAM. Hal ini disebabkan tidak terkaitnya peraturan perundang undangan yang ada dengan political will pemerintah. Ilmu politik berkaitan dengan tata negara, Tata negara berkaitan dengan pejabat-pejabat penting yang menetapkan arah kebijakan (policy) termasuk kebijakan tentang HAM. Bagi masyarakat sangat penting untuk mempelajari ilmu politik
\end{abstract}


agar masyarakat dapat turut mendorong political will pemerintah dalam bidang penegakan hukum hak asasi manusia di Indonesia.

Kata kunci : peran, ilmu politik, hak asasi manusia

\section{PENDAHULUAN}

Hak-hak Asasi Manusia sebagai gagasan, paradigma serta kerangka konseptual tidak lahir secara mendadak sebagaimana kita lihat dalam "Universal Declaration of Human Right" 10 Desember 1948 , namun melalui suatu proses yang cukup panjang dalam peradaban sejarah manusia (Kaelan, 2004). Hak - hak asasi manusia sebenarnya tidak dapat dipisahkan dengan pandangan filosofis tentang manusia yang melatarbelakanginya. Menurut Pancasila hakikat manusia adalah tersusun jiwa dan raga, kedudukan kodratnya sebagai makluk Tuhan dan makhluk pribadi, adapun sifat kodratnya sebagai makhluk individu dan makhluk sosial. Sebagai konsekuensi dalam realisasinya maka hak asasi manusia senantiasa memiliki hubungan yang korelatif dengan wajib asasi manusia karena sifat kodrat manusia sebagai individu dan makhluk sosial (Kaelan, 2004).

UUD 1945 sebagai konsitusi tertulis bangsa Indonesia mencantumkan Hak Asasi Manusia (selanjutnya disebut HAM ) ini baik dalam pembukaan maupun dalam batang tubuh nya serta penjelasan UUD 1945. Rincian HAM dalam UUD 1945 hasil amandemen 2002 (amandemen keempat) tertuang dalam pasal 28A sampai 28J UUD 1945, yang meliputi segala aspek kehidupan.

Sejarah bangsa Indonesia mencatat terjadinya berbagai pelanggaran HAM yang berat seperti kejahatan kemanusiaan yang terjadi di Timor Timur, Aceh, Jakarta, dan beberapa daerah lainnya yang belum tuntas penanganannya, padahal dibidang perundang-undangan Pemerintah Indonesia telah melakukan berbagai upaya untuk membuat undang undang maupun meratifikasinya dari berbagai instrumen internasional tentang HAM. Demikian pula penanganan dalam penegakan hukum dan peradilan HAM diharapkan dapat mengungkap tuntas kasus - kasus HAM, ternyata berhenti di tengah jalan atau kasusnya dikesampingkan (deponeer). Untuk masalah tersebut seharusnya kebijakan/politik yang melatarbelakangi terbentuknya peraturan perundang-undangan dan kebijakan dalam penanganan kasus yang diperlukan untuk hal tersebut harus berkesinambungan, dalam arti; walaupun telah berganti pejabat yang memangku jabatannya tapi kebijakan tetap dipakai hingga selesainya suatu kasus pelanggaran HAM.

Kansil (2000) menjelaskan bahwa dalam beberapa hal untuk mengetahui latar belakang dari suatu peraturan perundang-undangan sebaiknya perlu dibantu dengan mempelajari Ilmu Politik, karena kadang-kadang sukar diketahui maksudnya, serta bagaimana terbentuknya peraturanperaturan undang-undang itu. Keputusan-keputusan politik merupakan peristiwa-peristiwa yang banyak pengaruhnya pada tata negara.

Hubungan Ilmu Politik dan Tata Negara sangat erat terutama ditinjau dari sudut pandang kebijakan. Tata negara berkaitan dengan pejabat-pejabat penting yang menetapkan arah kebijakan (policy) termasuk kebijakan tentang HAM. 
Hubungan antara hukum dengan politik adalah bahwa hukum yang ada itu (maksudnya hukum positif) adalah putusan politik. Undang Undang Dasar di Indonesia dibuat oleh Majelis Permusyawaratan Rakyat (MPR) yang merupakan lembaga politik. Demikian seterusnya terhadap peraturan perundan-undangan lain sebagai pelaksanaan dari Undang-Undang Dasar, adalah juga keputusan politik. Hukum yang mengatur lembaga-lembaga politik itu adalah Hukum Tata Negara (bidang hukum lainnya adalah Hukum Perdata, Hukum Pidana, Hukum Administrasi Negara dan Hukum Internasional, dan masing-masing hukum ini berkembang dan terdiri dari hukum yang lebih spesifik dan bahkan sekarang berkembang apa yang disebut Hukum Bisnis. Karena itu hukum yang erat hubungannya dengan politik adalah Hukum Tata Negara. (Saragih, 2006)

Undang-Undang tentang HAM dan pelaksanaannya merupakan hasil kerja sama antara hukum dengan sistem kebijakan (negara), oleh karena itu pengetahuan politik dan ketatanegaraan merupakan hal yang urgen/penting dikuasai dan dipahami oleh penerus bangsa.

Dikaji dari latar belakang masalah di atas, adanya hak asasi manusia (HAM) sebagai hal utama yang harus ditempatkan sebagai prioritas kebijakan pejabat negara sebagai pembuat putusan politik, permasalahan yang muncul adalah bagaimana peran ilmu politik dalam mendukung HAM di Indonesia.

\section{METODE PENELITIAN}

Kajian ini bukanlah hasil riset mendalam berdasarkan metodologi-metodologi ilmiah yang ketat. Tulisan ini adalah hasil kajian mendalam berdasarkan penelusuran literatur yang difokuskan pada isu-isu yang dibahas. Tekanannya adalah pembahasan pada sumber-sumber tertulis dan hasil pengamatan sehari-hari dari penulis. Selain itu dilakukan juga kajian terhadap hasil-hasil riset yang dilakukan pihak lain, dan juga referensi terkait yang berhubungan dengan apa yang menjadi pokok bahasan.

\section{HASIL DAN PEMBAHASAN}

Miriam Budiarjo (2016) menjelaskan bahwa bila Ilmu Politik dipandang sebagai salah satu cabang dari ilmu-ilmu sosial yang memiliki dasar, rangka, fokus, dan ruang lingkup yang jelas, maka Ilmu Politik dianggap masih berusia muda, namun bila Ilmu Politik dilihat sebagai pembahasan secara rasional dari berbagai aspek negara dan kehidupan politik, maka Ilmu Politik merupakan ilmu-ilmu sosial yang tertua, walaupun masih bersandar pada sejarah dan filsafat.

Definisi Ilmu Politik secara sederhana adalah ilmu yang mempelajari politik/politics atau kepolitikan. Politik adalah usaha untuk menggapai kehidupan yang lebih baik. Istilah Ilmu Politik (Science politique) pertama kali digunakan oleh Jean Bodin di Eropa pada 1576, kemudian Thomas Fitzherbert dan Jeremi Bentham pada 1606. Tetapi istilah politik yang dimaksud ialah ilmu negara sebagaimana tertulis dalam karya-karya sarjana Eropa daratan yang bersifat institusional yuridis, sementara yang berkembang di Amerika adalah teori politik. Konsepsi teori politik yang dikembangkan di Amerika telah melepaskan diri dari sifat-sifat yang institusional yuridis dengan 
memberi pengertian yang lebih luas daripada ilmu negara. Dalam pandangan para sarjana Amerika, ilmu politik sebagai ilmu negara bukan lagi dalam pengertian institusi yang statis, tetapi lebih maju dengan melihat negara sebagai lembaga politik yang mempengaruhi kehidupan masyarakat. Oleh karena itu, definisi-definisi politik belakangan ini lebih banyak memberi tekanan pada negara dalam hubungannya dengan dinamika masyarakat seperti dibuat oleh Kaspar Bluntschli bahwa "politics is the science which is concerned with the state, which endeavors to understand and comprehend the state in its conditions, in its essential nature, it various forms of manifestation, its development." Bahkan Harold D. Laswell lebih tegas merumuskan politik sebagai ilmu tentang kekuasaan. "When we speak of the science of politics, we mean the science of power". ( Cangara, 2016).

Pada dasarnya ilmu politik tidak terlepas dari hubungan dengan cabang ilmu sosial lainnya, seperti : filsafat, ilmu hukum, sejarah, sosiologi, antropologi, ekonomi, psikologi dan geografi. Masyarakat yang menjadi obyek ilmu-ilmu sosial dapat dilihat sebagai sesuatu yang terdiri dari beberapa segi; ada segi ekonomi yang antara lain bersangkut paut dengan produksi, distribusi dan penggunaan barang-barang dan jasa-jasa ; ada pula segi kehidupan politik yang antara lain berhubungan dengan penggunaan kekuasaan dalam masyarakat; dan lain-lain segi kehidupan. (Soekanto, 2014).

Soerjono Soekanto menjelaskan bahwa, ilmu politik mempelajari suatu segi khusus pula dari kehidupan masyarakat yang menyangkut soal kekuasaan. Hal-hal yag dipelajari oleh ilmu politik adalah, misalnya, daya upaya untuk memperoleh kekuasaan, penggunaan kekuasaan dan juga bagaimana menghambat penggunaan kekuasaan dan lain sebagainya. Ilmu Politik dengan istilah politik yang dipergunakan sehari- hari dikalangan orang banyak, mempunyai perbedaan; politik diartikan sebagai pembinaan kekuasaan negara yang bukan merupakan ilmu pengetahuan tetapi merupakan seni (art). Ilmu politik menurut Contemporary Political Science, terbitan UNESCO 1950 dalam Budiardjo (2016) terbagi dalam 4(empat) bidang ilmu, yaitu: 1.1. Teori politik, 2. Lembaga-lembaga Politik, 3. Partai-partai, golongan-golongan (group) dan pendapat umum, 4. Hubungan Internasional.

Keempat bidang tersebut menegaskan bahwa ilmu politik sebagai bidang ilmu yang menggerakkan atau menghidupkan dinamika suatu negara dengan pemikiran-pemikirannya, keorganisasian, kebijakan yang diambil serta hubungan yang luas dalam suatu negara bahkan antar negara. Negara merupakan integrasi dari kekuasaan politik, negara adalah organisasi pokok dari kekuasaan politik. Negara adalah alat (agency) dari masyarakat yang mempunyai kekuasaan untuk mengatur hubungan-hubungan manusia dalam masyarakat dan menertibkan gejala-gejala kekuasaan dalam masyarakat.

Pemahaman politik sebagai studi kekuasaan telah mendapat kecaman dengan menempatkan politik dalam area yang sangat sempit, karena ilmu politik tidak hanya mempelajari kekuasaan semata-mata, melainkan juga mempelajari kerja sama antara individu atau pelaku-pelaku politik. Ilmu politik berusaha menciptakan harmonisasi dalam menciptakan keteraturan dalam masyarakat tanpa paksaan atau penggunaan kekuasaan. Lagi pula politik tidak hanya menyelidiki proses 
politik, tetapi juga ide-ide politik serta hakikat politik sebagai ilmu yang bisa menciptakan konsepkonsep atau model-model pemerintahan yang baik. Para pengecam khawatir bahwa ilmu politik pada akhirnya hanya akan melahirkan sejumlah teori tentang golongan yang berkuasa (ruling class) dan teori tentang elite politik, padahal yang tidak kalah penting adalah golongan yang diperintah yang lebih besar jumlahnya dari golongan yang memerintah. (Cangara, 2016).

Politik mempunyai beberapa pengertian yang berkaitan dengan perebutan kekuasaan , kedudukan, dan harta yang meliputi beberapa konsep, yaitu: Negara (state), kekuasaan (power), pengambilan keputusan (desicion making), kebijakan (policy, beleid) dan pembagian (distribution) atau alokasi (allocation) . Konsep -konsep tersebut mempunyai korelasi (hubungan ) yang erat dengan hukum tata negara dan administrasi pemerintahan. Sebagaimana disampaikan oleh Ossip K. Fletchtein bahwa ilmu politik adalah ilmu sosial yang khusus mempelajari sifat dan tujuan dari negara sejauh negara merupakan organisasi kekuasaan, beserta sifat dan tujuan dari gejala gejala kekuasaan lain yang dapat mempengaruhi negara.

Pada umumnya dapat dikatakan bahwa politik atau (politics) adalah usaha untuk menentukan peraturan yang dapat diterima baik oleh sebagian besar warga, untuk membawa masyarakat kearah kehidupan bersama yang harmonis. Usaha untuk menggapai "the good life" ini menyangkut bermacam-macam kegiatan yang antara lain menyangkut proses penentuan dari sistem, serta cara-cara melaksanakan tujuan itu. Masyarakat mengambil keputusan mengenai apakah yang menjadi tujuan dari sistem politik itu dan hal ini menyangkut pilihan antara beberapa alternatif serta urutan prioritas dari tujuan tujuan yang telah ditentukan itu.

Hafied Cangara menyampaikan meskipun begitu luasnya definisi ilmu politik yang disampaikan oleh beberapa pakar politik, baik aliran Eropa Kontinental berdasarkan aspek yuridis maupun Amerika dalam hubungan antar negara dengan masyarakat yang bersifat dinamis namun ilmu politik dalam pembahasannya dapat dilihat dari tiga (3) dimensi, yaitu;

politik sebagai studi kelembagaan (institusi), politik sebagai studi kekuasaan (power) dan politik sebagai studi Kebijakan Publik.

Selanjutnya Miriam Budiarjo, menjelaskan bahwa untuk melaksanakan kebijakan kebijakan umum (public policies) yang menyangkut pengaturan dan alokasi (allocation) dari sumber daya alam, perlu dimiliki kekuasaan (power) serta wewenang (authority). Kekuasaan ini diperlukan baik untuk membina kerjasama maupun untuk menyelesaikan konflik yang mungkin timbul dalam proses ini. Cara - cara yang dipakainya dapat bersifat persuasif (meyakinkan) dan jika perlu bersifat paksaan (coercion). Tanpa unsur paksaan, kebijakan ini hanya merupakan perumusan keinginan (statement of intent) belaka.

Kekuasaan Negara mempunyai kekuatan memaksa yang diatur berdasarkan ketentuan hukum, sebagaimana dijelaskan dalam Penjelasan UUD 1945, bahwa Negara Indonesia berdasarkan hukum (Rechtsaat) bukan berdasarkan kekuasaan semata (Macthstaat). Negara dalam sudut pandang ilmu politik disebut sebagai sistem politik, penerapannya dalam bentuk konkrit yaitu negara. Pada konsep sistem politik yang penerapannya dalam bentuk negara ini, ilmu politik mencoba mendasarkan studi tentang gejala politik dalam hubungannya dengan tingkah laku dalam 
masyarakat. Tingkah laku politik dianggap sebagai sebagian dari keseluruhan tingkah laku sosial. (Saragih, 2006: 7)

Pelaksanaan kekuasaan dilihat dalam masyarakat melalui saluran politik menurut Soerjono Soekanto, dijalankan oleh penguasa dan pemerintah dengan cara berusaha untuk membuat peraturan peraturan yang harus ditaati masyarakat. Caranya antara lain dengan meyakinkan atau memaksa masyarakat untuk menaati peraturan-peraturan yang telah dibuat oleh badan-badan yang berwenang dan sah. (Soekanto, 2014).

Berdasarkan sudut pandang ilmu politik, Indonesia sebagai negara demokrasi dimana kedaulatan ada ditangan rakyat, dalam pembuatan peraturan sebagai produk kebijakan berarti bahwa hasil dari peraturan atau keputusan yang ditetapkan berlaku dan supaya diikuti oleh semua orang yang berada di wilayah Negara Indonesia.

Disisi lain Hafied Cangara menjelaskan bahwa demokrasi adalah suatu sistem yang dijalankan melalui proses pemilihan yang dilakukan secara jujur dan terbuka, dimana semua kelompok yang ikut bertarung siap menerima hasilnya sebagai suatu realitas yang harus dihormati dan ditaati. Harus ada prinsip bahwa kelompok mayoritas memiliki kemungkinan untuk benar lebih banyak daripada berbuat kesalahan. Tetapi tidak berarti yang mayoritas harus menjadi tirani dan menghancurkan hak-hak minoritas, melainkan bagaimana menciptakan keseimbangan, sehingga tercipta apa yang disebut "majority power and minority right". Jadi mayoritas memiliki kekuasan dan minoritas memiliki hak, termasuk untuk respek terhadap mayoritas.

Ada 11 prinsip sistem pemerintahan yang demokratis menurut Melfin I. Urofsky, guru besar Sejarah dan Kebijakan Publik pada Virginia University, yaitu; 1. Pemerintahan berdasarkan konstitusi, 2.Pemilihan umum yang demokratis, 3. Pelaksanaan Desentralisasi/Otonomi daerah, 4. Pembuatan Undang-Undang, 5. Sistem Peradilan yang independen, 6. Kekuasaan lembaga Kepresidenan, 7. Peran Media massa yang bebas, 8.Peran kelompok-kelompok kepentingan (interest group), 9. Hak masyarakat utuk mengetahui (right to know), 10. Mengakui dan melindungi hak-hak minoritas, 11. Kontrol sipil atas militer.

Sistem pemerintahan yang disampaikan oleh Melfin tersebut adalah tipe sistem pemerintahan demokrasi yang ideal, dimana negara sebagai pemegang kekuasaan menempatkan 11 (sebelas) prinsip di atas untuk kepentingan masyarakat, bila prinsip-prinsip tersebut terpenuhi berarti juga adanya penghormatan terhadap hak-hak asasi manusia terpenuhi.

Hubungan ilmu politik dan hukum tata negara pertama tama ditunjukkan oleh Barent dengan perumpamaan HTN sebagai kerangka manusia, sedangkan ilmu politik merupakan daging yang ada disekitarnya. Hukum Tata Negara (HTN) menurut Ismail Suny, adalah hukum yang mengatur tentang organisasi negara dan pemerintah, hubungan antara pemerintah dan rakyat, dan hak-hak asasi warga negara.

Pembahasan negara dari segi hukum tata negara meliputi hak-hak asasi manusia, yaitu hak asasi warga negaranya. Kebijakan mengenai hak asasi ini tertuang dalam Pancasila yang di atur lebih lanjut dalam Pembukaan UUD 1945, dijabarkan dalam batang tubuh UUD 1945 dan penjelasannya. 
Abdussalam dalam tulisannya tentang “HAM Dalam Proses Peradilan” menyayangkan bahwa walaupun materi-materi dalam alinea ke satu sampai alinea ke empat Pembukaan UUD 1945 tersebut ada kesamaan dengan materi yang terdapat dalam Universal Declaration of Human Right (UDHR), United Nations General Assembly Resolution 217 A(III), 10 Desember 1968, dengan pembatasannya, namun materi dalam batang tubuh UUD 1945 tidak dirumuskan secara konkrit berdasarkan pada Pembukaan UUD 1945 tersebut sejak Pemerintahan Presiden R.I. Soekarno (Orde Lama) sampai berakhirnya Pemerintahan Presiden R.I Soeharto (Orde Baru). Baru pada Pemerintahan B.J Habibie mulai ditegakkan nilai-nilai demokrasi dan Hak-hak Asasi Manusia dalam bentuk kebijakan hukum.

Selanjutnya, kebijakan-kebijakan hukum yang diambil dalam kerangka penghormatan HAM dimulai dengan ; dikeluarkannya Ketetapan MPR R.I No. XVII/MPR/1998 tentang Hak Asasi Manusia pada tanggal 13 November 1998 dengan lampiran Piagam HAM. Kemudian disusun, disahkan dan diberlakukan Undang-Undang No. 39 Tahun 1999 tentang Hak asasi Manusia (HAM) tanggal 23 September 1999 dengan mengacu pada Ketetapan MPR tersebut.

Undang-Undang No 39 Tahun 1999 tersebut berisi prinsip-prinsip HAM yang mengadopsi dari $U D H R, I C C P R$ dan ICESOCR, yang memuat hak-hak juga kewajiban dasar manusia serta mengatur Komisi Nasional Hak Asasi Manusia (KOMNAS HAM). Dengan terjadinya kejahatan terhadap manusia (Crime Against Humanity) di Timor Timur pasca jajak pendapat tahun 1999, maka disusun disahkan dan diberlakukan Undang-undang R.I No. 26 Tahun 2000 Tentang Pengadilan HAM dan pembentukan Pengadilan Ad Hoc HAM terhadap kasus Timor Timur tersebut.(Abdussalam, 2010)

Sejarah bangsa Indonesia hingga kini mencatat penderitaan, kesengsaraan dan kesenjangan sosial, yang disebabkan oleh perilaku tidak adil dan diskriminatif atas dasar etnik, ras, warna kulit, budaya, bahasa, agama, golongan, jenis kelamin dan status sosial lainnya. Perilaku tidak adil dan diskriminatif tersebut merupakan pelanggaran hak asasi manusia, baik yan bersifat vertikal (dilakukan oleh aparat negara terhadap warga negara atau sebaliknya) maupun horizontal (antar warga negara sendiri) dan tidak sedikit yang masuk dalam kategori pelanggaran hak asasi manusia yang berat (gross violation of human rights)

Ketimpangan pelaksanaan hak-hak asasi tersebutlah yang menimbulkan berbagai pelanggaran hak atau pelanggaran HAM yang tercatat dalam lembaran sejarah bangsa Indonesia, hingga saat ini belum dapat dituntaskan.

Masalah-masalah hak asasi manusia menurut H.A.W Widjaja (2000) dalam meningkatkan pertumbuhan ekonomi dan mewujudkan stabilitas politik yang dibutuhkan untuk menunjang kegiatan-kegiatan ekonomi kadang-kadang mengenyampingkan atau mengabaikan sama sekali perhatian terhadap pemenuhan hak-hak kebebasan politik, kebebasan berkumpul dan berserikat serta mengeluarkan pendapat.

Masalah hak asasi lainnya dijelaskan oleh H.A.W Widjaja sebagai warisan penjajahan yang tidak pernah memprioritaskan kepentingan rakyat kecil, warisan itu menggejala di segala bidang 
kehidupan, bidang politik, ekonomi, sosial budaya yang meskipun dalam kondisi bangsa telah merdeka masih terus berlanjut. Hal ini karena penguasa memakai ideologi sebagai landasan melegitimasikan tindakan tindakannya untuk mempertahankan kekuasaan politiknya yang bersifat dominan. H.A.W Widjaja menyebut ketidak adilan struktural tersebut dengan sebutan penindasan politik yang mematikan hak-hak politik rakyat. Hak asasi manusia di Indonesia telah mengalami pasang surut. Sesudah dua periode represi (rezim Soekarno dan rezim Soeharto), reformasi berusaha lebih memajukan hak asasi. Akan tetapi dalam kenyataannya harus menghadapi tidak hanya pelanggaran hak secara vertikal tetapi juga secara horisontal. Pelaksanaan hak politik mengalami kemajuan, tetapi pelaksanaan hak ekonomi masih belum dilaksanakan secara memuaskan.

Miriam Budiardjo mendiskripsikan tentang tahun-tahun pertama reformasi yang ditandai oleh konflik horisontal, antara lain di Ambon, Poso, dan Kalimantan, di mana pelanggaran hak asasi dilakukan oleh kelompok-kelompok masyarakat sendiri. Aparat penegak hukum nampaknya tidak mampu atau tak bersedia menangani berbagai sengketa ini. Mungkin juga ada rasa enggan karena tuntutan masyarakat agar semua pelanggaran hak asasi ditindak, menimbulkan keraguan di kalangan prajurit dan polisi di lapangan mengenai tindakan mana yang dibolehkan, dan mana yang dilarang.

Akan tetapi dalam masa Reformasi pemenuhan hak asasi ekonomi telah mengalami kemunduran tajam. Sekalipun banyak faktor internasional mempengaruhi ekonomi Indonesia, akan tetapi tidak sedikit faktor internal yang menyebabkannya. Faktor eksternal adalah kemerosotan ekonomi di seluruh dunia, dan reaksi dunia atas peristiwa bom Bali dan gerakan antiterorisme. Faktor internal menyangkut kegagalan pemberantasan korupsi, manajemen sistem bank, dan peraturan berbagai aspek kehidupan ekonomi lainnya. Ditambah dengan akibat dari berbagai konflik sosial disejumlah daerah yang mengakibatkan bengkaknya jumlah pengungsi, terlantarnya pendidikan, dan kerugian kolateral yang perlu dibangun kembali. Beberapa kemajuan yang telah dicapai di bidang pertumbuhan ekonomi, pemberantasan pengangguran, dan pendapatan perkapita mengalami kemunduran. (Miriam Budiardjo , 2016)

Beberapa kasus pelanggaran berat Hak Asasi Manusia (HAM) yang terjadi dalam perjalanan sejarah bangsa Indonesia, antara lain : Genosida (Pembantaian satu suku bangsa (di Timor Timur) pada tahun 1999 yang terjadi setelah referendum atau pemisahan daerah Timor Timur atau sekarang yang lebih dikenal dengan Timor Leste yang berujung terjadinya kasus pelanggaran berat HAM berupa kekerasan, pembunuhan massal, kerusakan pemukiman penduduk dalam skala besar yang di duga terjadi sebagai bentuk kekecewaan atas lepasnya satu daerah teritori mereka. Pada tahun 2005 Pemerintah RI dan Pemerintah Timor Leste membuat sebuah komisi mengungkap kebenaran mengenai kasus HAM di Timor Leste pada rentang waktu 1974 sampai 1999 , yaitu Komisi Kebenaran dan Persahabatan (KKP).

Laporan KKP tahun 2008 merekomendasikan antara lain, Pemerintah Indonesia dan Timor Leste bekerja sama untuk menjelaskan nasib dan keberadaan dari mereka yang hilang dan dihilangkan, membentuk suatu program pemulihan bagi para korban khususnya korban kasus 
pemerkosaan dan kejahatan lain, dan bagi pemerintah Indonesia untuk mengakui dan meminta maaf atas penderitaan yang di buat tahun 1993. Namun, beberapa LSM baik internasional maupun nasional seperti Amnesti Internasional, ANTI dan Kontras memandang kinerja dari KKP sendiri belum cukup memuaskan dan menuntut kepada pemerintah Indonsia dengan bantuan komunitas internasional untuk mendukung upaya keadilan dan kebenaran bagi korban pelanggaran HAM di Timor Leste yang terjadi selama pendudukan Indonesia berlangsung. (Kompasiana.com)

Peristiwa lain yang terjadi yaitu Gerakan Aceh Merdeka (GAM) yang dimulai jauh sebelum reformasi, yaitu sejak adanya deklarasi kemerdekaan aceh oleh M.Hasan di Tiro tanggal 4 Desember 1976. GAM ingin memisahkan diri dari Indonesia dengan beberapa usaha termasuk kekerasan. Gerakan dibawah kepemimpinan M.Hasan di Tiro ini berhasil ditumpas, namun 1980 GAM menguat kembali dengan nama Angkatan Gerakan Aceh Merdeka (AGAM). AGAM menghimpun kekuatan untuk memerdekaan diri dari Pemerintahan Indonesia dengan dikirimnya 400 anggotanya ke Libya untuk latihan militer, dan mulai menyerang pemerintah tahun 1989 hingga tahun 1992, di tahun 1992 inilah pemerintah baru dapat mengendalikan sepenuhnya dan menghentikan gerakan mereka.

Deretan peristiwa Agresi militer yang terjadi di Aceh yang berkaitan dengan kekerasan dan hak asasi manusia tersebut tidak lepas dari sorotan publik, disusul lengsernya Presiden Soeharto setelah kasus kerusuhan politik Mei 1998. Peristiwa 12 Mei 1998 (kasus Trisakti) yang dimulai dengan unjuk rasa mahasiswa, hingga turun ke jalan menuju gedung MPR/DPR, walaupun mereka dihadang satu peleton Dalmas Polres Jakarta. Negosiasi wakil mahasiswa dengan wakil birokrasi Kampus (Dekan Fakultas Hukum Trisakti) yang disertai Kapolres dan Dandim Jakarta Barat berlangsung lama hingga mahasiswa kembali kekampus jam105 WIB, namun disayangkan pada saat itulah terjadi penyerangan oleh aparat keamanan yang mengakibatkan 4 mahasiswa tertembak mati dan banyak yang luka-luka.

Menhankam/ Pangab memerintahkan agar pelaku kasus penembakan 4 mahasiswa ini diproses hukum dan diajukan ke Mahkamah Militer. Pengusutan peristiwa, penyelidikan dan proses hukum yang dilakukan ternyata menyebabkan ketegangan antara polisi dan militer karena diduganya anggota pihak polisi yang menembak, disisi lain kesulitan dalam pembuktian senjata dan longsong peluru yang digunakan tidak sesuai dengan semua jenis senjata yang di pakai oleh seluruh anggota polisi dan Brimob Polri, sehingga tidak didukung oleh pembuktian materiil. Dengan belum diproses hukum aatas matinya 4 mahasiswa Trisakti sampai saat ini, maka telah terpenuhi unsur pelanggaran HAM dalam konflik bersenjata.

Disusul konflik tanggal 13, 14 dan 15 Mei 1998 terhadap Pemerintah Daerah Jakarta oleh oknum oknum tertentu yang berkelompok di berbagai wilayah Jakarta. Pihak Mabes RI mengeluarkan Rencana Pengamanan dengan nama Operasi Mantap ABRI dengan dibagi dalam 3 tahap. Puncak kerusuhan berupa pengrusakan, penjarahan , pembakaran, perkosaan , pelecehan, yang mengakibatkan kerugian materiil dan korban jiwa tersebut terjadi tanggal 14 Mei 1998 hampir disebagian besar wilayah Jakarta. Persiapan pengamanan atas perintah Mabes tersebut bahkan tidak terlaksana pada saat puncak kerusuhan tersebut, datang setelah terjadinya kerusuhan dengan 
alasan Pangab RI beserta staff Mabes RI, Panglima Kostrad beserta staff meninggalkan Jakarta ke Malang untuk meresmikan dan serah terima komando Pengendalian Pasukan Pemkul Reaksi Cepat (PPRC) dari Divisi I ke Divisi II. Karena sampai saat ini belum diproses hukum pembiaran aparat keamanan pemerintah terhadap kerusuhan Jakarta tersebut maka telah terpenuhi unsur pelanggaran HAM. (Abdussalam, 2010).

Pelanggaran HAM dilihat dari dua (2) aspek, yaitu; dalam aspek substansi dan aspek prosedural. Kedua aspek tersebut dibagi lagi dalam keadaan damai dan keadaan konflik bersenjata. Pelanggaran HAM yang disampaikan diatas sebagai contoh kasus Timor timur, Aceh dan Jakarta adalah pelanggaran HAM dari aspek prosedural dengan konflik bersenjata sebagaimana dijelaskan oleh Abdussalam dalam buku "HAM Dalam Proses Peradilan".

Ditinjau dari Konstitusi yang menentukan bahwa Indonesia adalah negara hukum (rechtsaat) dimana supremasi hukum terletak pada tempat tertinggi, seharusnya beberapa pelanggaran HAM yang terjadi harus diusut tuntas dalam penegakan keadilan dan kebijakan politik pemerintah (political wiil).

Daniel S. Lev menjelaskan bahwa peranan yang dimainkan oleh hukum, sebagai pranata dan mitos politik, sangat bergantung pada hasil pertentangan politik. Di Indonesia, hukum bagi berbagai kelompok terlihat sebagai jalan untuk melepaskan diri dari keadaan politik dan ekonomi yang merugikan atau sebagai sarana untuk meenata kembali berbagai hubungan antara negara dan masyarakat berdasarkan landasan moral baru. Walaupun kekuatan yang mendukung negara hukum masih mengalami kekalahan dalam perjuangan gagasannya (pembentukan Undang-Undang) namun perselisihan ini terus berlanjut terhadap pemerintah di pengadilan maupun forum pemerintahan lainnya, tentang persoalan hak-hak asasi, perilaku pejabat, jaminan prosedural, dan batas-batas kekuasaan politik dan hak prerogratif pejabat, dimana gagasan demikian cenderung membawa pengaruh dalam evolusi politik Indonesia. (Lev, 2013)

Pengetahuan tentang kebijakan atau politik ketatanegaraan, peraturan perundang-undangan serta pemahaman tentang suatu bentuk negara yang berdasarkan keadilan sosial bagi seluruh rakyat Indonesia (sebagaimana ditegaskan dalam Sila ke-5 Pancasila), dapat diperoleh melalui jalur pendidikan.

Undang-undang Sisdiknas (Sistim Pendidikan Nasional) No.20 Tahun 2003 menyebutkan bahwa: ..." Pendidikan Nasional adalah pendidikan yang berdasarkan Pancasila dan UndangUndang Dasar Negara Republik Indonesia tahun 1945 yang berakar pada nilai-nilai agama, kebudayaan nasional Indonesia, dan tanggap terhadap tuntunan perubahan zaman." Oleh karena itu ilmu politik di tingkat perguruan tinggi dimulai dengan pendalaman materi tentang Pancasila sebagai dasar negara kita.

Pengetahuan tentang ilmu-ilmu lain yang tak dapat dilepaskan dari pembahasan ilmu politik memberikan bekal untuk mengetahui dinamika kehidupan manusia dari segala aspek termasuk pendalaman agama dan norma-norma, pendidikan dan pengetahuan tentang demokrasi Pancasila, pendidikan dan pengetahuan tentang HAM serta hukum sebagai produk sistim politik. 
Di bidang hukum (sebagai produk dari kebijakan politik) ada banyak upaya untuk memperbaiki peraturan perundang-undangan dan bertujuan untuk menegakkan supremasi hukum , antara lain dibentuknya lembaga-lembaga baru disamping lembaga-lembaga yang sudah ada seperti Komisi Nasional Hak Asasi Manusia (Komnas HAM) yang awal pembentukannya berdasarkan Keputusan Presiden (Keppres ) No. 50 Tahun 1993. (Miriam Budiardjo , 2016). Lembaga-lembaga baru tersebut, antara lain adalah : 1. Komisi Hukum Nasional (KHN), 2. Komisi Pemberantasan Korupsi (KPK), 3. Komisi Nasional Anti Kekerasan Terhadap Perempuan, 4. Komisi Ombudsman Nasional (KON).

Beberapa dari komisi di atas telah terbentuk saat ini, namun perlu didukung dengan peraturan perudang-undangan yang lebih menekankan hak-hak asasi sebagai prioritas utama, sebagai syarat pembangunan hukum nasional. Undang- undang Republik Indonesia Nomor 10 Tahun 2004 tentang Pembentukan Peraturan Perundang-undangan, mengatur : 1. bahwa pembentukan peraturan perundang-undangan merupakan salah satu syarat dalam rangka pembangunan hukum nasional yang hanya dapat terwujud apabila didukung oleh cara dan metode yang pasti, baku, dan standar yang mengikat semua lembaga yang berwenang membuat peraturan perundang-undangan. 2. bahwa untuk lebih meningkatkan koordinasi dan kelancaran proses pembentukan peraturan perundang-undangan, maka negara Republik Indonesia sebagai negara yang berdasar atas hukum perlu memiliki peraturan mengenai pembentukan peraturan perundang-undangan. 3 . bahwa selama ini ketentuan yang berkaitan dengan pembentukan perundang-undangan terdapat dalam beberapa peraturan perundang-undangan yang sudah tidak sesuai lagi dengan hukum ketatanegaraan Republik Indonesia. 4.. bahwa berdasarkan pertimbangan sebagaimana di maksud dalam huruf a, huruf $b$, dan huruf c, perlu membentuk Undang-Undang tentang Pembentukan Peraturan Perundang-undangan.

Binsar Gultom (2010) merangkum beberapa hal yang perlu dilaksanakan untuk antisipasi pencegahan pelanggaran HAM, dan pelaksanan hukum darurat yang diharapkan,antara lain: 1 . Penyempurnaan aturan perundang-undangan, 2. Efektifitas UU No. 26 Tahun 2000 tentang Pengadilan HAM, 3.Peningkatan pemahaman masyarakat dibidang HAM.

Karena masyarakat adalah bagian tak terpisahkan dari pejabat/aparatur penegak hukum di bidang HAM, masyarakat "harus" menerima berbagai pendidikan atau pelatihan di bidang HAM baik formal maupun nonformal. Dengan harapan mereka dapat mengaktualisasikan pengetahuan itu ketika mereka menghadapi berbagai masalah di bidang HAM. Dengan demikian, berbagai tindakan yan bersifat tidak manusiawi, misalnya pembunuhan sadis dapat dieliminasi.

Mahasiswa adalah bagian masyarakat yang terkelola dalam lingkungan kampus dan pendidikan, dan diharapkan merekalah yang akan menerima tampuk pimpinan dan pemerintahan selanjutnya. Sebagai pemimpin mereka perlu dibekali pengetahuan yang menyeluruh baik dari segi agama, Pancasila dan Kewarganegaraan, hukum dan perundang-undangan, perekonomian, sosial budaya, teknologi lainnya. Namun untuk menjadi seorang pimpinan yang bijak dan mampu membuat keputusan yang tepat serta mengatasi masalah ketatanegaraan dan mencapai kesejahteraan rakyat sebagaimana cita-cita bangsa Indonesia, mereka harus memahami, menguasai 
dan dapat menerapkan ilmu politik yang berdasarkan norma-norma agama dan dasar negara kita Pancasila.

\section{KESIMPULAN}

Ilmu Politik bukan hanya sekedar pengetahuan dan pengantar peserta didik kedunia kerja dan masyarakat saja, namun merupakan bekal utama untuk mengarahkan peserta didik sebagai pembuat kebijakan dalam bentuk putusan politik yang dapat mengatasi masalah-masalah penting dalam ketatanegaraan, perancangan peraturan perundang-undangan, kebijakan dalam perekonomian dan sosial budaya, kependudukan, agraria, kesempatan kerja dan alternatif lapangan kerja, dan terutama menanggulangi masalah-masalah yang menyangkut hak asasi manusia (HAM) yang menentukan arah kehidupan bangsa Indonesia.

Untuk membentuk kader-kader/pemimpin bangsa yang berkualitas, cerdas dan berkarakter, seharusnya materi ilmu politik berbobot keagamaan dan norma-norma, wawasan kebangsaan dan cinta tanah air, kerjasama dan tenggang rasa serta penguasaan materi untuk dapat menghasilkan keputusan yang tepat atau kebijakan. 
Vita Justisia, Peran IImu Politik Dalam Mendukung Hak Asasi Manusia di Indonesia, JSSP, Vol. 2, No. 2, Desember 2018

\section{DAFTAR PUSTAKA}

Abdussalam. (2010). HAM Dalam Proses Peradilan. Jakarta: PTIK PREES.

Budiardjo, Miriam. (2016). Dasar-dasar Ilmu Politik. Jakarta: PT. Gramedia Pustaka.

Cangara, Hafied. (2016). Komunikasi Politik, Konsep, Teori dan Strategi, Jakarta: PT. RajaGrafindo Persada.

Gultom, Binsar. (2010). Pelanggaran HAM Dalam Hukum Keadaan Darurat di Indonesia. Jakarta: PT. Gramedia Utama Pustaka.

Kaelan. (2000). Pendidikan Pancasila. Yogyakarta: Penerbit Paradigma.

Kansil. C.S.T. (2000). Hukum Tata Negara. Jakarta: PT. Rineka Cipta.

Soekanto, Soerjono. (2014). Sosiologi Suatu Pengantar. Jakarta: PT. RajaGrafindo Persada.

Saragih, Bintan Regen. (2006). Politik Hukum, Bandung: CV. Utomo.

S Lev , Daniel. (2013). Hukum Dan Politik Di Indonesia, Kesinambungan Dan Perubahan. Jakarta: IP3ES, anggota IKAPI.

Widjaja, H.A.W. Widjaja. (2000). Penerapan Nilai-nilai Pancasila dan HAM d Indonesia. Jakarta: Rineka Cipta. 